\title{
Teaching and learning in secondary and post-secondary education: views of undergraduate art and design students in the United Arab Emirates
}

\author{
Nicos Souleles \\ Cyprus University of Technology, Limassol
}

\section{Introduction}

One indication of the UAE's emphasis on education is the statement in the UAE Government Strategy (2010) that national social development and advancement can be achieved if student academic achievements in secondary and post-secondary education reach higher standards. This objective relates to the aspiration of the UAE to join the global knowledge economy through the contributions of university graduates who have the skills and competencies to facilitate this transition. However, at the secondary and post-secondary levels there are obstacles that hinder this objective. Among the challenges in secondary education are instructional methods that promote learning styles unsuitable for student progression in $\mathrm{HE}$, such as rote learning and content memorisation (Crabtree, 2010). Consequently, universities in the UAE invest a large proportion of their effort and funds to address learning deficiencies at the undergraduate level (Fox, 2008). For example, most undergraduate students are required to complete a Foundation learning course to support the development of language and learning skills that are necessary for completing HE programmes.

In the UAE there is a minimal or non-existent provision of art and design subjects in secondary education, where the emphasis is predominantly upon maths, sciences and languages. After Grade 9, a few students have the choice to undertake art and design subjects as extracurricular activities (Farah \& Ridge 2009). Studies indicate that despite the emphasis on maths, sciences and languages, in terms of the level of student achievements the UAE rates below other nations against which it wants to be compared (Farah \& Ridge 2009). According to some research, the significance of art and design education is not limited to developing knowledge about the related domain of knowledge, but extends into allowing students to develop high order learning skills (such as creative and critical thinking skills), which are transferable to other domains (Arts Education Partnership, 1999). In turn, this implies that if art and design subjects are introduced in secondary education, students will be better equipped with the learning competencies and skills that will allow them to progress more successfully through $\mathrm{HE}$ without the significant requirement of remedial assistance that is now in place.

This paper investigates the perceptions of undergraduate art and design students about their secondary education in the UAE. In particular, it investigates their views on teaching and learning methods, and what they think about the lack of art and design subjects in secondary education. Undergraduate students in art and design carry with them the influence of secondary education learning styles (often rote learning and memorization) and are confronted with the learning requirements of post-secondary art and design curricula (involving more critical thinking, independent learning, project-based learning and collaborative learning). The objective of this study is to identify the educational challenges these students face vis-à-vis learning style requirements in $\mathrm{HE}$, and to compare these to the learning competencies they acquired in secondary education. To what extent do the learning skills acquired at

Souleles, N. (2013). Teaching and learning in secondary and post-secondary education: views of undergraduate art and design students in the United Arab Emirates. Learning and Teaching in Higher Education: Gulf 
the secondary education level prepare undergraduate students to effectively study art and design at post-secondary level? What are the implications of this in terms of preparing graduates for the global knowledge economy, and in supporting the UAE's agenda on this front?

This overview of the context and purpose of this paper is followed by an elaboration on the global and regional conditions as well as the benefits of art and design education, the research methodology and associated limitations and delimitations, the analysis of data and conclusions.

\section{Global imperatives, local conditions}

There is considerable consensus that the structure of work in advanced economies is shifting away from traditional manufacturing modes of production, towards the provision of services and the production, management and circulation of knowledge through Information and Communication Technologies (ICT's) (Saunders, 2000). The terms 'knowledge economy' and 'information society' are used in parallel in this paper, to suggest a strong association between these two terms. States internationally are responding to growing requirements for trained citizens as economies increasingly depend upon knowledge-related skills and the ability to handle information. Education and training are now being perceived as instruments of economic policy: states that adopt an interventionist approach through education and training as well as through labour market policies aim to facilitate the development of high-wage, high-skill post-Fordist economies (Dudley, 1998). The need for a more highly skilled workforce to service new information-related industries and participate in the knowledge economy is a high priority for many states. To this can be added the need for re-skilling, career changes and life-long learning. According to one estimate, a person will need to retrain at least five times in a working lifetime and such retraining requires the equivalent of three months of full-time learning (Bates, 2000).

The changes in the nature of industry and society both reflect upon and affect HE curricula. At least at policy level many universities accept the political and economic agenda associated with the knowledge economy. Most have a commitment to the development of skills and accept the role of the state and employers in contributing to their curricula. In fact, "a review of both national and international literature suggests that a consensus has emerged with regard to diagnosing the needs of the future economy and the prognosis of the skills base" (Bennet, Carre \& Dunne, 2000, p. 106). There are calls to re-consider what constitutes 'graduateness' and preparedness in the context of employment in the knowledge economy. Here too there is a dominant rhetoric and common themes emerge to provide an account and range of desired skills. For example, Goodyear (2001) argues:

Employers rarely rate specialised knowledge as the key factor determining whether they will hire graduates. This knowledge... is liable to obsolescence... [Employers] value intellectual flexibility, logical analysis, ability to conceptualise issues rapidly and to deal with large amounts of information... employers are looking for transformative potential: willingness to learn, ability to deal with change and question assumptions, analytic, critical and problem-solving skills... (p. 5)

Similarly, Barnett (1997) contends:

Transferable skills and core skills are simply the code for the kinds of capability now being sought; adaptability and flexibility are indications of the kinds of disposition now required. These are metaskills. Not only do they enable persons to deploy effectively a repertoire of generic and more specific skills, but also make it possible for the self-reflexive individual ultimately to jettison particular skills and take on new ones. (p. 3)

A summary of global HE imperatives indicates the characteristics of the prevalent discourse. Firstly, the almost universal acceptance that there are skills and competencies that should be developed and

Souleles, N. (2013). Teaching and learning in secondary and post-secondary education: views of undergraduate art and design students in the United Arab Emirates. Learning and Teaching in Higher Education: Gulf 
advanced and that these are congruent with participation in the knowledge economy. Secondly, the significant role of $\mathrm{HE}$ in fostering and promoting this set of skills. HE institutions in the UAE are confronted with this agenda and this is characteristically encapsulated in the following statement:

Our nation will set and achieve increasingly ambitious educational targets. A progressive national curriculum will extend beyond rote learning to encompass critical thinking and practical abilities, equipping our youth with essential skills and knowledge for the modern world. In terms of such practical competencies - as well as high scores on standard international examinations - our children's educational achievements will place them on a par with students in the most advanced nations (UAEInteract, 2010).

However, the obstacles in existence in the local milieu of secondary and post-secondary education are well known and documented. Ineffective teaching methods at secondary education are predominantly based on rote learning and this hinders the development of dialogue, critical thinking, and the analysis and communication skills required for higher learning. The need to move towards student-focused learning environments and away from didactic approaches is constantly emphasized. In addition, there are inappropriate assessment methods which grade memorization rather than skills and understanding. There is poor or limited use of ICT's, mostly for non-teaching and learning purposes (Macpherson, Kachelhoffer \& Nemr, 2007).

In post-secondary education, massification of $\mathrm{HE}$ in the Emirates has opened university education to a wider spectrum of Emirati society and even though $\mathrm{HE}$ institutions and funding bodies are aware of the potential role they can play to contribute towards participation in the global knowledge economy (Wagie \& Fox, 2005), underfunding is creating obstacles to these aims (Kirk \& Napier, 2009). Added to these challenges is the burden of students' joining HE with learning styles that are inappropriate for university study. It has been claimed that a university degree in the UAE tends to be associated with prestige rather than content and that a significant percentage of undergraduate students cheat in their exams (Zerougui 2011). This combination of massification of education, underfunding and inappropriate learning styles is not unique to the UAE but is a general problem faced by other Arab universities (El-Baz, 2007; World Bank, 2007). In summary, it appears that the educational skills that would facilitate a successful transition from secondary to post-secondary education are not being taught: research indicates that in the UAE a large number of incoming students are not ready to learn at university level (Fox, 2008).

\section{Benefits of art and design education}

In England, the objective of the art and design programme of study for key stage 3 (early secondary education) as articulated by the Qualifications and Curriculum Authority, is to develop student competencies in investigating, analysing, designing, reflecting, evaluating effectively, and making informed choices about media, techniques and processes (Qualifications and Curriculum Authority, 2007). However, the seemingly uncritical acceptance of the development of such competencies through the study art and design subjects in early secondary education does not mean that there is no debate on the transfer of such skills to other areas of the curriculum and their overall contribution to improved learning.

In a report compiled by the Arts Education Partnership (1999), the potential positive impact of the arts on learning includes: a) the encouragement of self-directed learning, b) the promotion of complexity and multi-dimensionality in the learning experience, c) the attainment of higher levels of achievement, and $d$ ) increased motivation and engagement. The authors argue that due to the benefits of educating

Souleles, N. (2013). Teaching and learning in secondary and post-secondary education: views of undergraduate art and design students in the United Arab Emirates. Learning and Teaching in Higher Education: Gulf 
students in the arts, these must become a basic part of the learning experience in secondary education. To support these claims the report provides data comparing the performance of two groups of students in Grades 8, 10 and 12. The first group undertook more art classes and, when compared to the second group, demonstrated an improved performance in diverse subjects such as English, reading, history, citizenship and geography (1999). However, the authors caution that there may not be an obvious causal link between the improved performance and undertaking arts subjects: the connection may simply be attributed to the fact that good students tend to perform well irrespective of the subjects they study and 'rubbing shoulders' with high-performing art-loving students is of benefit in itself.

Eisner (1999) reviewed research published from 1986 to 1996 on the relationship between arts courses and academic achievement. He focused on studies where the data and methods could be appraised and concluded that there is no clear evidence of transfer and increased achievement due to students undertaking art subjects prior to post-secondary education. However, he argues, there is some evidence of improved attitude, i.e. students who performed well in arts were more motivated in other subjects. In the decade since Eisner's (1999) conclusions a lot has changed in the way young people learn. This is the main contention of Lee \& Breitenberg (2010), who assert that the young learners of the present time are the first generation born in the digital age. Instruction in a linear fashion and learning restricted mainly to classrooms is replaced by multi-dimensional modes of ubiquitous learning not limited by time or place; it involves the assembly and grouping of diverse media such as text, images, and sound. These instructional methods entail learners who are proactive rather than reactive. Instructional methods associated with art and design education, such as student-centered and project-based learning can utilize the shift required towards instructional strategies that are more relevant to learners. Further, technology-enhanced art and design curricula can facilitate constructivist learning, which in turn helps to promote high order skills through independent and collaborative learning.

This change in the way young students learn alters the primary emphasis of teaching art and design education from promoting through traditional means (lecture, tutorial, criticism) knowledge of visual and aesthetic literacy, to developing an understanding of how best to use multiple media and electronic communication networks in the context of the discipline (Delacruz, 2009). The benefits of an art and design education are no longer restricted to the intellectual understanding of the work and influence of Impressionism or Bauhaus. In using as a vehicle the natural affordance of the art and design domain of knowledge for new and exciting methods of learning to take place, such methods are transferable to other contexts and promote high-order learning skills and competencies.

\section{Delimitations, limitations and data}

From the limited research on disciplinary differences in teaching and learning we know that academics in 'soft' disciplines such as humanities and the arts, in comparison to their colleagues in 'hard' domains of study such as medicine and engineering, spend more time on teaching and less in laboratories and research. Curricula in the former area tend to be open-structured, while the latter are ordered mostly around well-defined concepts and principles. Consequently, academics in soft disciplines place greater importance on broad, general knowledge and effective critical thinking skills, while in hard fields of study there is more emphasis on ability to apply methods and principles (Neumann, 2001). This distinction between domains of knowledge and the explicit ramifications for teaching and learning is highlighted by Braxton, Olsen \& Simmons (1999) who draw the difference between disciplines of high and low paradigmatic development. Paradigmatic development refers to the extent to which members of a discipline agree about theory, methods and techniques. In low paradigmatic disciplines such as humanities and the arts, there is more emphasis on discursive and student-centered instructional

Souleles, N. (2013). Teaching and learning in secondary and post-secondary education: views of undergraduate art and design students in the United Arab Emirates. Learning and Teaching in Higher Education: Gulf 
practices. This brief reference to disciplinary differences helps to explain the need to delimit this paper to one - albeit broad - domain of academic knowledge, i.e. art and design.

The data for this paper were gathered through an online survey of thirty-eight undergraduate art and design students in a HE institution in the UAE. The disciplines represented in the data are: fine arts, graphic design, interior design, fashion design and jewelry design. Undergraduate students from these disciplines were contacted through email, and they were invited to participate in the online survey on a voluntary basis and anonymously. Consequently, the percentage of representation in the data for each discipline is not known, nor is the age and gender of the respondents. Female undergraduate students outnumber their male counterparts across the whole of the HE sector in the UAE (Fox 2008, 121) and this is likely the case with the data for this paper.

The questions that comprise the survey emerged out of prolonged discussions with undergraduate art and design students and were piloted with a small sample of the target population. Due to practical restrictions, it was not feasible to include in this study a larger number of participants from different Emirati universities. Consequently, the outcomes of this survey cannot claim wider generalizability for the number of participants is small and the data was gathered through convenience sampling. The outcomes of this study offer a small-scale snapshot at a particular point in time and within a limited context. They provide descriptive, inferential and indicative information that can inform further largescale research.

\section{Analysis of data}

Each question is followed by an elaboration of its significance, the breakdown of responses in terms of percentages and numbers, identification of the emerging theme or themes, and where available indicative statements which encapsulate these themes. Percentages were rounded up or down to the nearest integer. The appendix shows the survey questions, the answers available to choose from and the results before they were rounded up or down.

\section{Were you taught art and design subjects in secondary school?}

It was appropriate to start the survey by asking respondents to confirm whether they were taught any art and design subjects in secondary school. 74 per cent (response count $=28$ ) of the respondents provided a negative reply and 26 per cent (response count $=10$ ) a positive answer (Figure 1 ).

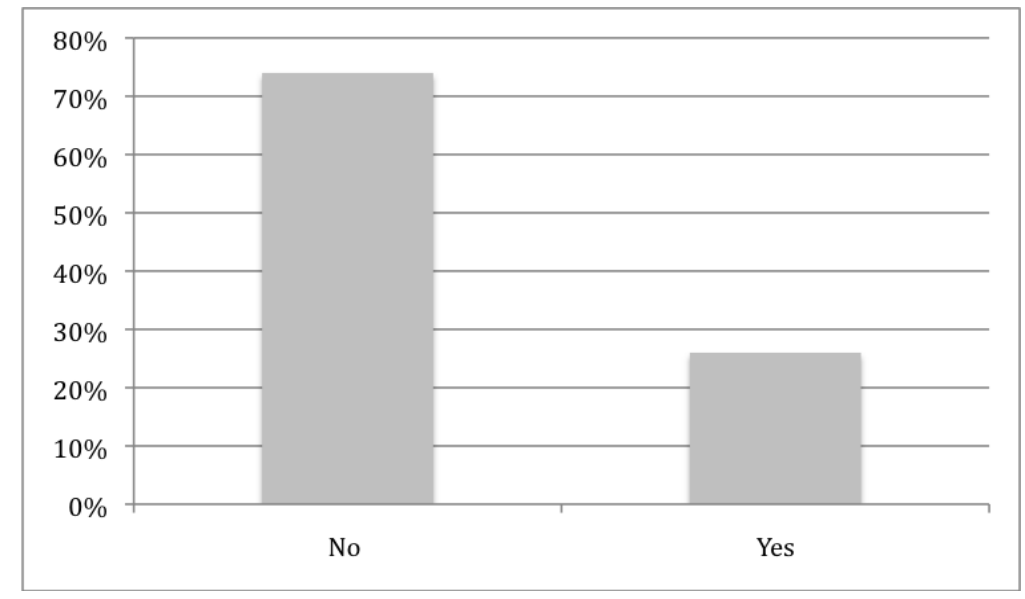

Figure 1: Teaching of art and design subjects in secondary school.

Souleles, N. (2013). Teaching and learning in secondary and post-secondary education: views of undergraduate art and design students in the United Arab Emirates. Learning and Teaching in Higher Education: Gulf 
Considering that art and design subjects are not part of the compulsory curriculum and are only offered as optional extracurricular activities, we can assume that the 'yes' group had only superficial exposure to art and design subjects. This is confirmed by comments that accompany the replies, such as "We had basic arts and crafts sessions", "Art wasn't taken seriously at all", and "Art classes were very general".

\section{How were the teaching and learning methods in secondary school?}

Respondents were allowed to provide a number of replies to this question and were not limited in their choice of answers. Despite the emphasis on didactic methods in secondary education, the question aims to reveal if any other instructional approaches were in use. 82 per cent (response count $=31$ ) replied that they had to memorize a lot. 40 per cent (response count $=15$ ) participated in question and answer sessions. 26 per cent (response count $=10$ ) were encouraged to discuss and critique. 21 per cent (response count $=8$ ) were involved in independent learning. 13 per cent (response count $=$ five) experienced workshops (Figure 2).

The first observation that can be made from the data shown is that didactic methods dominate the style of learning and teaching that takes place in secondary schools in the UAE. Figure 2 indicates that rote learning - which entails memorization - prevails over other instructional methods in secondary schools. The relationship between instructional methods that require a higher level of student independent learning and the percentage of corresponding responses is inversely proportionate: as more responsibility for learning shifts to the students, the amount of responses becomes smaller. For example, workshops entail an element of experimentation, thinking 'outside the box', and dealing with the unexpected. This seems to be the least preferred instructional method. As for the pedagogic value of question and answer sessions in terms of promoting independent and critical thinking skills, it is likely to be minimal, for in the context of the prevailing teaching and learning regime such sessions are likely to serve only to consolidate the dominant view of the teacher and not to encourage debate, critical thinking and analysis.

The following indicative comments by some of the respondents encapsulate student teaching and learning experiences: 'It was never about the learning, it was about not failing and making sure you pass everything', 'The teaching style was bad', 'Memorising is what they taught us', and 'There were no workshops of any kind'.

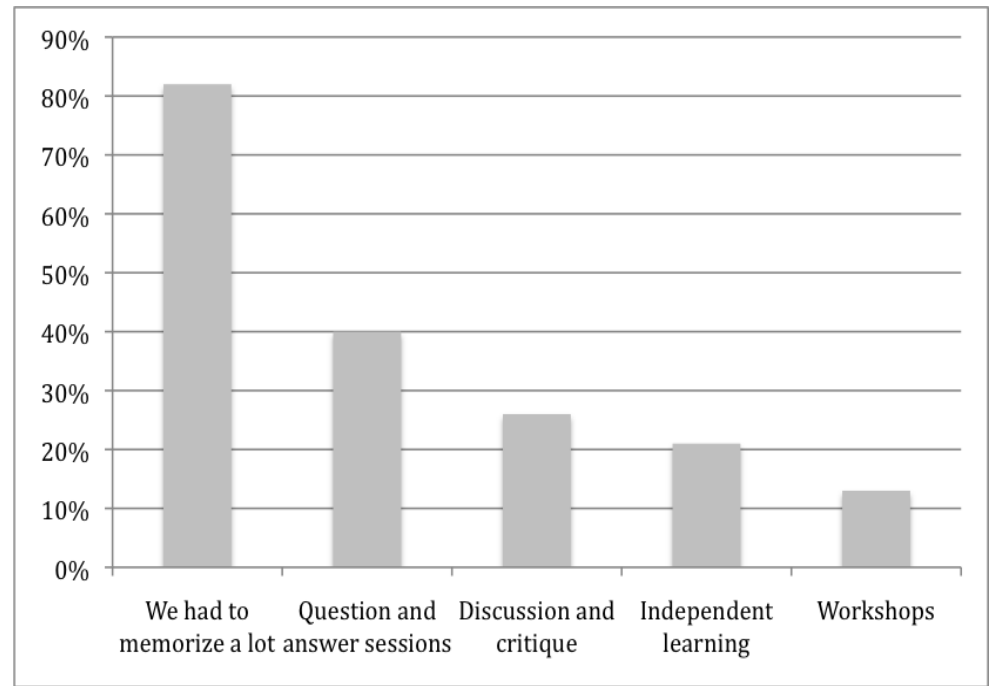

Figure 2: Teaching and learning methods in secondary school.

Souleles, N. (2013). Teaching and learning in secondary and post-secondary education: views of undergraduate art and design students in the United Arab Emirates. Learning and Teaching in Higher Education: Gulf 


\section{How well did secondary education prepare you to study art and design at university level?}

This question deals with the perception of undergraduate students in terms of the contribution of secondary education in preparing them for the demands of learning in $\mathrm{HE}$. It has a retrospective quality for respondents reflected upon past experiences in secondary education and comparing these with current teaching and learning experiences in post-secondary education. 97 per cent (response count $=$ 37) of the respondents stated that secondary education did not prepare them well and three per cent (response count $=1$ ) provided a positive answer (Figure 3 ).

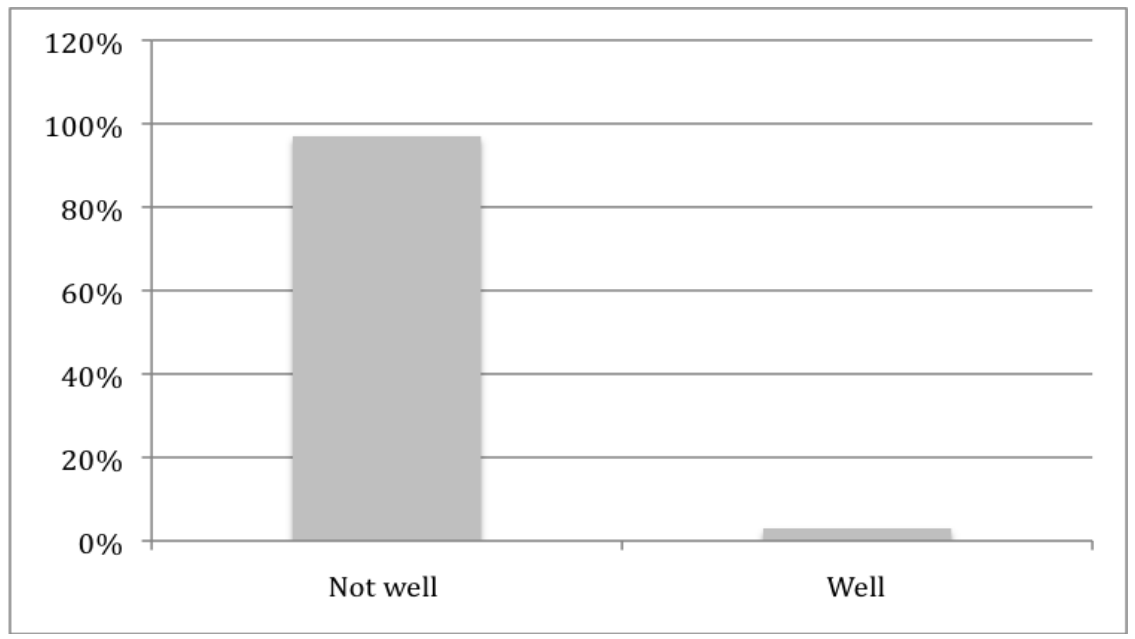

Figure 3: How well did secondary education prepare you to study in higher education?

From the data, the emerging theme is overwhelmingly clear. The majority of respondents consider secondary education as having failed to prepare them for the learning and teaching experiences of postsecondary art and design education. The following statements are indicative of this theme: "Scientific subjects were more important to teachers", "Art classes were more like breaks in the learning routine", and "They never asked us what we want to do at university".

\section{How do you consider that secondary education could prepare you to study in HE?}

While the previous question was specific about art and design, this one is more general and thus seeks to expand upon the previous one. Respondents were allowed to choose from a number of replies and were not limited to a single answer (Figure 4).

It was expected that a large percentage of undergraduate students who participated in this survey would have wanted to undertake art and design subjects during secondary education. However, the high percentage $(82$ percent, response count $=31$ ) that chose this reply in comparison to the second largest group for this question (37 percent, response count $=14$ ) indicates a majority desire for art and design subjects in comparison to different instructional methods during secondary education. The difference between these two groups is almost fifty percent. Finally, perhaps because the question does not relate directly to art and design subjects - as in the previous question - about one quarter of respondents ( 24 percent, response count $=9$ ) considered that secondary education prepared them well for HE. The following indicative statements by the respondents provide some context for the above data: "High school has prepared me very well, had I decided to join a more scientific course [at university]", and "They did not prepare me to study art and design".

Souleles, N. (2013). Teaching and learning in secondary and post-secondary education: views of undergraduate art and design students in the United Arab Emirates. Learning and Teaching in Higher Education: Gulf 


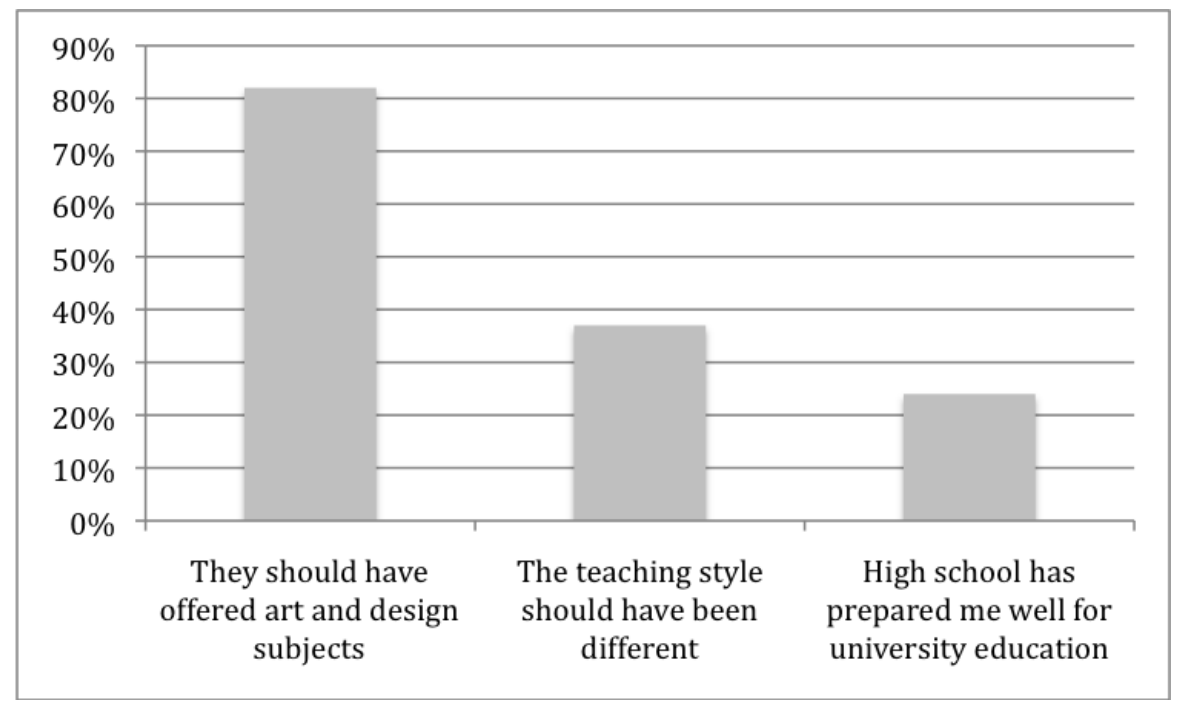

Figure 4: How could secondary education prepare for study in HE?

\section{What skills and competencies do you consider that you are developing while studying art and design at university level?}

The aim of this question is to ask respondents to reflect on the benefits of their undergraduate art and design education, and to elaborate on what learning outcomes they value most from their postsecondary studies. As with the previous survey question, respondents were allowed to select from a number of replies and were not restricted to a single answer (Figure 5).

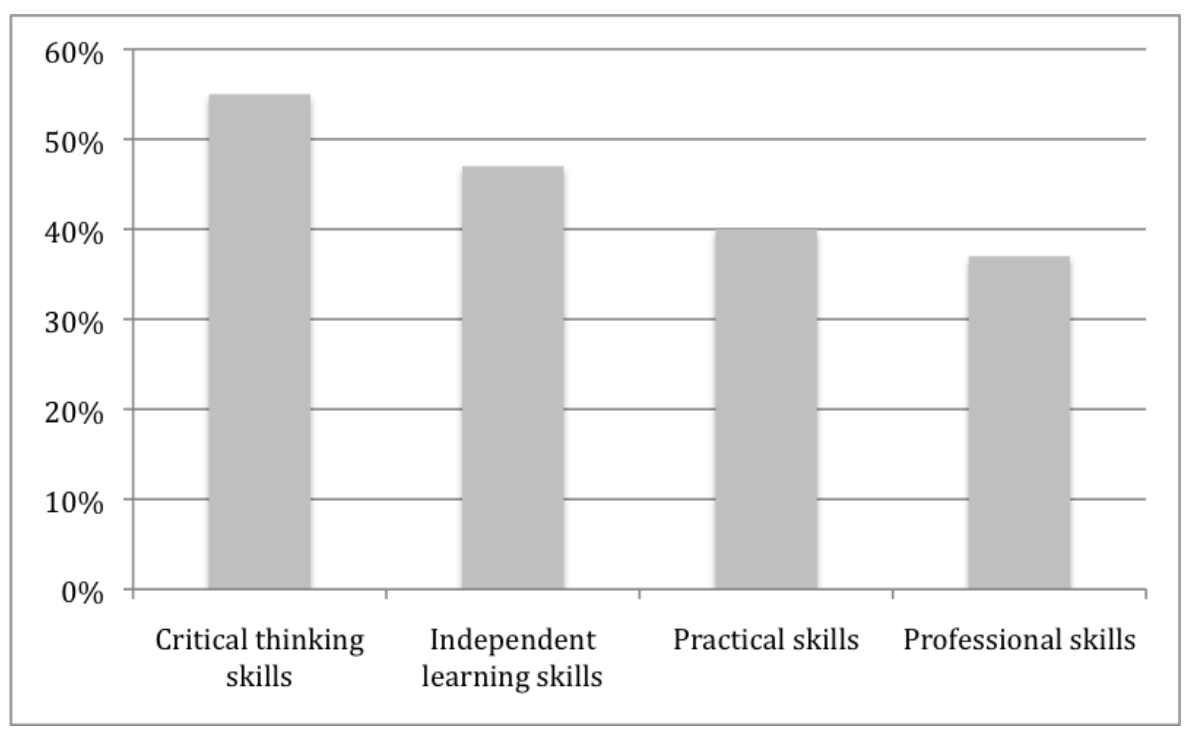

Figure 5: Skills and competencies developed while studying art and design at university level.

At some stage during their post-secondary studies the respondents are likely to have engaged in learning activities that required demonstration of critical thinking skills. They are likely to have participated in various degrees in instructional practices that required them to logically apply know-how in problem-solving contexts and to demonstrate sound judgement that they had to defend with rational justifications. The majority of respondents (55 percent, response count $=21$ ) rated this as the most

Souleles, N. (2013). Teaching and learning in secondary and post-secondary education: views of undergraduate art and design students in the United Arab Emirates. Learning and Teaching in Higher Education: Gulf 
significant competency they developed. This is followed by independent learning skills (47 percent, response count $=18$ ), i.e. the ability to pursue and complete an instructional task with minimal formative assessment. Due to the vocational nature of most art and design programmes, it was expected that practical know-how would rate highly. However, this ranks in third position in terms of responses. 40 percent (response count $=15$ ) of respondents value the practical competencies they developed. This can include varied skills such as knowing how to use software, expertise in pattern cutting, or in the use of various tools and media. 37 percent (response count $=14$ ) of respondents consider that the competencies and skills acquired through their undergraduate art and design studies offer them the opportunity to become professional in their chosen area of study. The fact that this rates lower than critical thinking and independent learning provides a hint that learning per se is valued higher than acquiring expert or professional skills. The following indicative responses provide some context for the above data: "Presentation skills, communication skills", "Practical thinking", and "Thinking and brainstorming skills".

\section{A university degree is important because...}

This question is an extension to the previous one. If critical thinking, independent learning skills, practical skills and professional competencies are what the respondents value the most, it would be useful to know what they expect to achieve on completion of their post-secondary studies in art and design. Respondents were allowed to select from a number of replies and were not restricted to a single answer (Figure 6).

The surprising outcome from this question is that the majority of respondents ( 82 percent, response count $=32$ ) consider that an undergraduate qualification is significant for the knowledge acquired per se, and the prospect of gaining employment is second to this (59 percent, response count $=23$ ). The huge gap between these two groups and those who consider that an undergraduate degree is useful in terms of prestige (three percent, response count $=1$ ) significantly undermines the claim that a university degree in the UAE is associated with prestige rather than content.

The following indicative statements illustrate the above points: "I appreciate learning deeply about what I love to do and in the right way. I want to become a professional in the future", "An undergraduate degree expands your horizon and contributes in making the world better", and "An undergraduate degree prepares me to do things professionally".

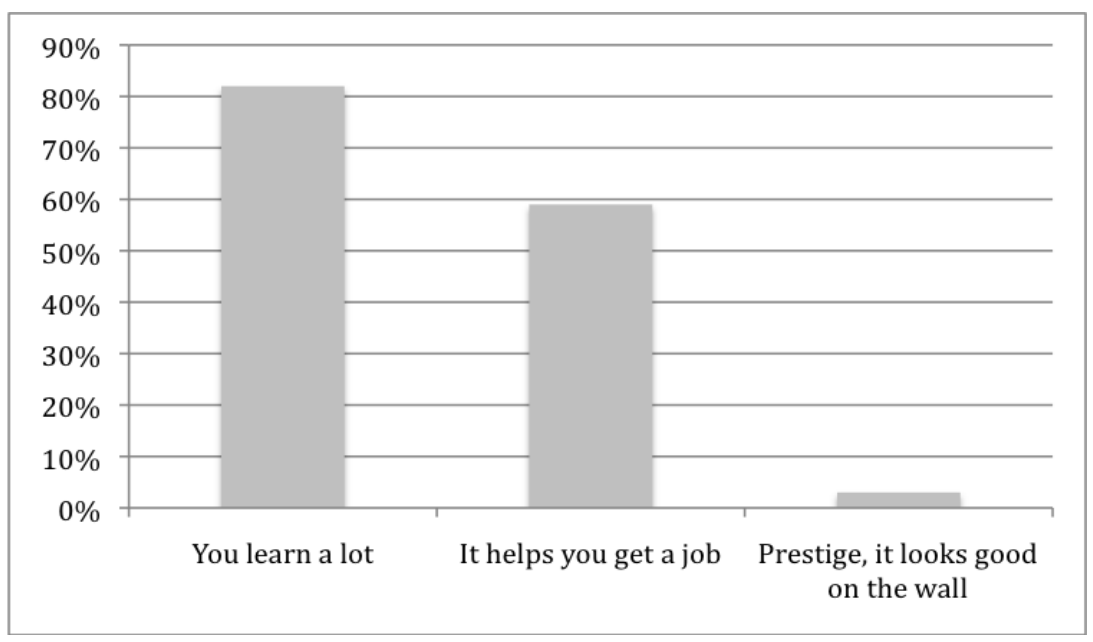

Figure 6: A university degree is important because...

Souleles, N. (2013). Teaching and learning in secondary and post-secondary education: views of undergraduate art and design students in the United Arab Emirates. Learning and Teaching in Higher Education: Gulf 


\section{Conclusion}

The purpose of this paper was to investigate the views of undergraduate art and design students on their teaching and learning experiences in secondary and post-secondary education in the UAE. The significance of this investigation relates to the aspiration of the UAE that through appropriate education and in particular, through graduates that successfully complete post-secondary studies, it can join the knowledge economy. Consequently, the learning skills acquired at secondary level are of importance in preparing students to study effectively and successfully at undergraduate level.

It has been argued that the study of art and design subjects during secondary education can foster the development of skills and competencies that are transferable to different domains of knowledge, as well as facilitating modes of instruction that are appropriate for HE. We espouse the view that there are natural affordances possible for innovative teaching to take place within the domain of art and design studies. These can allow for the practice of improved instructional methods, particularly when combined with meaningful use of digital tools and electronic communications. Such instructional methods are more relevant to the multimodal way students learn through the combination of different media. In addition, they can be student-centred as opposed to teacher-centred.

A number of attitudes are indicated by data gathered via a qualitative survey of 38 undergraduate art and design students. In the view of the majority of respondents to this survey, the comprehensive lack of art and design subjects in the curricula of secondary education, combined with the predominance of didactic methods of instruction, does not prepare secondary students well for the study of art and design at undergraduate level. However, about a quarter of respondents consider that the emphasis upon maths, sciences and languages together with the prevailing teaching style in secondary education in the UAE, does prepare them well for the study of other non-art and design disciplines. Further studies can explore disciplinary differences of progression within HE and possible causal links to teaching and learning in secondary education, i.e. the connection(s) between teaching and learning in secondary education and how this relates to the study of medicine, engineering, humanities or other disciplines

A majority of respondents view critical thinking as the most significant educational benefit of their undergraduate art and design studies, followed by independent learning. The prospect of employment possible due to an undergraduate qualification in art and design comes second to the high esteem with which the majority of respondents consider learning. Thus it can be argued that in terms of attitude and motivation, undergraduate art and design students provide a fertile ground for teaching and learning to take place that is congruent with instructional methods that can facilitate participation in the knowledge economy. This approach can be strengthened further and is important in transitioning the UAE in its move towards the development of a knowledge economy. It would also mean that if more strategic use was made of the positive attitude towards active student learning in secondary education, then less effort and funding could go towards addressing learning deficiencies at the undergraduate level. This would further be supported if the UAE were to implement a systematic introduction of art and design subjects in secondary education in the context of practices that place less emphasis on didactic methods of instruction and more effort on student-centered approaches to learning.

\section{References}

Arts Education Partnership. (1999). Champions of change: the impact of the arts on learning. Washington DC. Retrieved 23 June 2011 from http://www.aep-arts.org/publications/

Souleles, N. (2013). Teaching and learning in secondary and post-secondary education: views of undergraduate art and design students in the United Arab Emirates. Learning and Teaching in Higher Education: Gulf 
Barnett, R. (1997). Towards a Higher Education for a new century. London: Institute of Education, University of London.

Bates, A.W. (2000). Managing Technological Change, Strategies for College and University Leaders. San Francisco: Jossey-Bass.

Bennett, N., Carre, C., \& Dunne, E. (2000). Skill development in Higher Education and employment. In Coffield, F. (Ed.)., Differing visions of a Learning Society (pp.105-37). Bristol: The Policy Press.

Braxton, J., Olsen, D. \& Simmons, A. (1999). Affinity disciplines and the use of principles of good practice for undergraduate education. Research in Higher Education, 39(3), 299-318.

Crabtree, S. A. (2010). Engaging students from the United Arab Emirates in culturally responsive education. Innovations in Education and Teaching International, 47(1), 85-94.

Delacruz, E. (2009). Old World teaching meets the new digital cultural creatives. Journal of Art \& Design Education, 28(3), 261-268.

Dudley, J. (1998). Globalization and education policy in Australia. In J. Currie \& Nerwson J. (Eds.)., Universities and globalization: critical perspectives, (pp. 21-43). London: Sage.

Eisner, W.E. (1999). Does experience in the arts boost academic achievement? The Clearing House, 72(3), 143-149.

El-Baz, F. (2007). Reform in Arab countries: the role of education. The Journal of Education, 188(3), 41-49.

Farah, S., \& Ridge, N. (2009). Challenges to curriculum development in the UAE. Dubai School of Government Policy Brief, No. 16.

Fox, W.H. (2008). The United Arab Emirates and policy priorities for Higher Education. In C. Davidson \& P.M. Smith (Eds.)., Higher Education in the Gulf States: shaping economies, politics and culture (pp. 110125). London: Saqi.

Goodyear, P. (2001). Psychological foundations for networked learning. In Steeples, C. \& Jones, C. (Eds.), Networked learning. Springer.

Kirk, D., \& Napier, D. (2009). The transformation of Higher Education in the United Arab Emirates: issues, implications, and intercultural dimensions. Nation-Building, Identity and Citizenship Education, 3(11), 131-142.

Lee, H.K., \& and Breitenberg, M. (2010). Education in the new millennium: the case for design-based learning. Journal of Art and Design Education, 29(1), 54-60.

Macpherson, R., Kachelhoffer, P., \& Nemr, M. E. (2007). The radical modernization of school and education system leadership in the United Arab Emirates: towards indigenized and educative leadership. International Studies in Educational Administration, 35(1), 60-77.

Neumann, R. (2001). Disciplinary differences and university teaching. Studies in Higher Education, 26(2), 135-146.

Qualifications and Curriculum Authority. (2007). Art and design programme of study for key stage 3 and attainment target. Retrieved June 242011 from http://www.qca.org.uk/curriculum

Saunders, M. (2000). Understanding education and work: themes and issues. In R. Moon, B. Pereetz \& M. Brown (Eds.)., The international encyclopedic dictionary of education. (pp.1003-1029). Routledge.

Souleles, N. (2013). Teaching and learning in secondary and post-secondary education: views of undergraduate art and design students in the United Arab Emirates. Learning and Teaching in Higher Education: Gulf 
UAE Government. (2010). Highlights of the UAE Government Strategy. Leadership, Integration, Excellence. Retrieved December 19, 2010, from http://www.uaeinteract.com/government/ UAEGovtStrategyEng.pdf

UAE Interact (2010). Cabinet releases UAE Vision 2021. WAM, Emirates News Agency. Retrieved February 7, 2013, from

http://www.uaeinteract.com/docs/Cabinet_releases_UAE_Vision_2021_\%28full_text\%29/39555.htm

Wagie, D., \& Fox, W. (2005). Transforming higher education in the United Arab Emirates (UAE). International Journal of Learning, 12(7), 277-86.

World Bank (2007). The road not traveled: education reform in the Middle East and North Africa, Executive Summary. Washington DC: The World Bank.

Zerougui, A. (2011). From where I sit: Gulf between aims and outcomes. Times Higher Education. Retrieved May 8, 2011 from http://www.timehighereducation.co.uk 


\section{Appendix: The survey questionnaire with responses}

$\begin{array}{lll}\begin{array}{l}\text { Question 1: } \\ \text { Were you taught art and } \\ \text { design subjects in secondary } \\ \text { school? }\end{array} & \begin{array}{l}\text { Response } \\ \text { Percent }\end{array} & \begin{array}{l}\text { Response } \\ \text { Count }\end{array} \\ & & \\ \text { Yes } & 27.5 \% & 11 \\ \text { No } & 72.5 \% & 29\end{array}$

\section{Question 2:}

How were the teaching and learning methods in secondary school?

We had to memorise a lot.

$82.5 \%$

33

We were encouraged to

$27.5 \%$

11

discuss and critique.

We had workshops.

$12.5 \%$

5

We had question and answer

$40.0 \%$

16

sessions.

We had some independent

$20.0 \%$

8

learning.

Any other related

$40.0 \%$

16

comments:

It was never about the learning, it was about not failing and make sure you pass everything.

The teaching style was bad.

Memorising is what they taught us.

There were no workshops of any kind.

It was basically a simple art and craft sessions.

Studying books.

Souleles, N. (2013). Teaching and learning in secondary and post-secondary education: views of undergraduate art and design students in the United Arab Emirates. Learning and Teaching in Higher Education: Gulf 
Memorise.

Everything was based on learning and memorizing, and teachers were focusing on scientific subjects a lot.

No.

Doing presentations.

No comments.

We covered only the basic subjects that need to be learnt like Maths, English, Biology etc.

It was a combination between memorizing and answering sessions.

No comment.

No comment.

No comment.

\section{Question 3:}

How well did secondary education prepare you to study art and design at university level?

Not well.

$95.0 \%$ 38

Well.

\section{Question 4:}

How do you consider that secondary education could prepare you to study in $\mathrm{HE}$ ?

They should have offered art and design subjects. 
have been different.

High school has prepared me $\quad 22.5 \%$

9

well for university education.

\section{Question 5:}

What skills and

competencies do you

consider that you are

developing while studying

art and design at university

level?

Software skills.

$37.5 \%$

15

Critical thinking skills.

$52.5 \%$

21

Independent learning skills.

$47.5 \%$

19

Professional skills.

$37.5 \%$

15

Other responses:

$20.0 \%$

8

Presentational skills, communication skills.

Building up the personality and the way of thinking.

Practical thinking.

Teaching the basics.

Social skills.

They [the teachers] had no knowledge about Art and

Design.

Thinking and brainstorming skills.

It depends on the person himself.

\section{Question 6:}

A university degree is important because...

You learn a lot. 
Prestige, it looks good on the $2.5 \%$

1

wall.

It helps you get a job.

$60.0 \%$

24

Other:

$20.0 \%$

8

I appreciate learning deeply

about what I love to do and

in the right way. I want to

become a professional in the

future.

University expertise is very important and if a student learns from it that would be very convenient.

An important step to achieve future goals.

It prepares me to do things professionally.

I can take advantage of what college is offering.

It expands your horizon and contributes in making the world better.

It is a weapon to defend yourself.

I learn a lot from professionals and wellexperienced people. 